\title{
Performance of lambs under four levels of dietary supplementation and artificially mix-infected with Haemonchus contortus and Trichostrongylus colubriformis
}

\author{
Efeito de quatro dietas na performance de cordeiros artificialmente infectados \\ com Haemonchus contortus e Trichostrongylus colubriformis
}

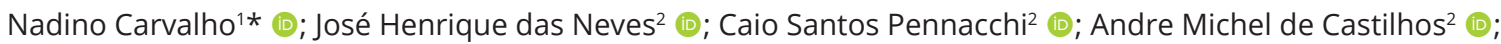
Alessandro Francisco Talamini do Amarante ${ }^{3}$ (i)

\footnotetext{
${ }^{1}$ Departamento de Medicina Veterinária, Fundação Universidade Federal de Rondônia - UNIR, Rolim de Moura, RO, Brasil ${ }^{2}$ Faculdade de Medicina Veterinária e Zootecnia, Universidade Estadual Paulista - UNESP, Botucatu, SP, Brasil ${ }^{3}$ Instituto de Biociências, Universidade Estadual Paulista - UNESP, Botucatu, SP, Brasil
}

How to cite: Carvalho N, Neves JH, Pennacchi CS, Castilhos AM, Amarante AFT. Performance of lambs under four levels of dietary supplementation and artificially mix-infected with Haemonchus contortus and Trichostrongylus colubriformis. Braz J Vet Parasitol 2021; 30(1): e025420. https://doi.org/10.1590/S1984-29612021010

\begin{abstract}
The effect of four diets on the performance of Dorper lambs that were artificially mix-infected with 1000 infective larvae (L3) of Haemonchus contortus and 1000 L3 of Trichostrongylus colubriformis every three days for 12 weeks was evaluated. For each diet, one infected group $(n=7)$ and one control group $(n=4)$ were set up. The four diets contained the following proportions of hay $(\mathrm{H})$ and concentrate $(\mathrm{C})$ : Diet $1-100 \% \mathrm{H}$; Diet $2-75 \% \mathrm{H}: 25 \% \mathrm{C}$; Diet 3 50\% H:50\%C; Diet $4-25 \% \mathrm{H}: 75$. All the infected groups showed decreases in mean packed cell volume (PCV) and total plasma protein, especially the Diet 1 -infected, which was also the group with the highest fecal egg count. The diets and infection had significant effects $(P<0.05)$ on daily body weight gain (DBWG), cold carcass weight and daily food consumption. The control and infected groups had mean DBWG (in kg), respectively, of 0.048 and 0.025 with Diet 1; 0.082 and 0.067 with Diet 2; 0.188 and 0.189 with Diet 3; and 0.303 and 0.221 with Diet 4 . In conclusion, the infection affected the productive performance regardless of the diet; however, with increased metabolizable protein and energy, the risk of occurrence of anemia and hypoproteinemia diminished.
\end{abstract}

Keywords: Prophylaxis, nematode, nutrition, dietary protein, sheep, Ovis aries.

\section{Resumo}

Avaliou-se o efeito de quatro dietas sobre o desempenho de cordeiros Dorper infectados artificialmente, a cada três dias, durante 12 semanas, com 1.000 larvas infectantes (L3) de Haemonchus contortus e 1.000 L3 de Trichostrongylus colubriformis. Um grupo infectado $(n=7)$ e um controle $(n=4)$ foram constituídos para cada uma das dietas, que continham a seguinte proporção de feno (F) e concentrado (C): Dieta 1 - 100\%F; Dieta 2 75\%F:25\%C; Dieta 3 - 50\%F:50\%C; Dieta 4 - 25\%F:75\%C. Todos os grupos infectados apresentaram redução nas médias de hematócrito (VG) e proteína plasmática total (PPT), principalmente o grupo Dieta 1 infectado, que também apresentou maior contagem de ovos nas fezes. Houve efeito significativo da dieta e da infecção $(P<0,05)$ no ganho em peso médio diário, peso da carcaça e consumo diário de alimento. Os grupos controle e infectado tiveram ganho em peso médio diário (em kg), respectivamente, de 0,048 e 0,025 na Dieta 1; 0,082 e 0,067 na Dieta 2; 0,188 e 0,189 na Dieta 3; e 0,303 e 0,221 na Dieta 4. Concluiu-se que a infecção afetou o desempenho produtivo independentemente da dieta, porém, com o aumento da proteína e da energia metabolizável, o risco de ocorrência de anemia e hipoproteinemia diminuiu.

Palavras-chave: Profilaxia, Nematoda, nutrição, dieta, ovinos, Ovis aries.

Received November 4, 2020. Accepted February 1, 2021.

*Corresponding author: Nadino Carvalho. E-mail: nadino@unir.br 


\section{Introduction}

Haemonchus contortus and Trichostrongylus colubriformis are the gastrointestinal nematodes (GINs) with the highest prevalence and infection intensity in sheep in Brazil (Wilmsen et al., 2014; Almeida et al., 2018a). They cause high losses due to reduced performance, mortality and costs of treatments. Furthermore, they present high capacity to develop anthelmintic resistance, which jeopardizes prophylaxis against parasitic infections (Albuquerque et al., 2017; Flávia da Silva et al., 2018; Salgado et al., 2019).

Given that the demand for nutrients that are necessary for defense of the organism is high, the productive performance of animals that are responding to challenges caused by pathogens is usually worse than that presented by infection-free animals (Greer, 2008; Cardia et al., 2011). The costs and consequences resulting from the development of the immune response, as well as pathological changes caused by parasitism, can compromise productivity. This is particularly so during the process of acquisition of immunity in young sheep (Greer, 2008; Cardia et al., 2011). An estimate through meta-analysis indicated that the performance of sheep that are infected with nematodes is only $85 \%$ of the performance of uninfected individuals, with regard to weight gain (Mavrot et al., 2015).

GINs have a negative effect on dry matter intake and live-weight changes among lambs. However, it has been suggested that the metabolic cost of GIN infection can be covered by supplying an additional requirement for protein and energy in the diet of infected lambs (Méndez-Ortíz et al., 2019). Therefore, immuno-nutrition is an alternative that can easily be adopted by farmers in order to minimize the losses caused by GIN infections (Hoste et al., 2016).

Dorper is a breed of hair sheep that has becoming very popular in Brazil since its introduction into this country a few decades ago. However, these sheep show high susceptibility to GIN infections (Mugambi et al., 1997). In a study on grazing Dorper lambs that were naturally infected with GINs and subjected to two nutritional statuses, it was demonstrated that supplemented lambs that underwent suppressive treatment with an anthelmintic (control group) showed a daily body weight gain $17.1 \%$ higher than that of the infected group counterpart that underwent targeted selective treatment with an anthelmintic. Among the lambs that received the baseline diet, the difference between the infected and control groups was the largest, at 26.7\% (Starling et al., 2019).

Therefore, as a continuation of the study on Dorper lambs (Starling et al., 2019), the present experiment was carried out with the aim of determining, under controlled conditions of infection and nutrition, what influence four levels of dietary supplementation would have on the performance of Dorper lambs that were serially infected with $H$. contortus and $T$. colubriformis.

\section{Material and Methods}

All procedures involving animals in this study were conducted in accordance with international ethical standards and were approved by the local Ethics Committee on Animal Use (protocol number 78/2014-CEUA, FMVZ/UNESP).

\section{Description of the experiment}

We acquired 44 Dorper lambs from a commercial farm. They were three months old and had been raised indoors since birth, under conditions of low exposure to helminth infections. On arrival at the university facilities, nematode fecal egg counts (FEC) by means of the McMaster technique (Ueno \& Gonçalves, 1998) demonstrated that two animals had 100 eggs per gram of feces (EPG) of Strongyloides papillosus and neither of them was shedding strongylid eggs. However, through using the Willis method, which is more sensitive (Ueno \& Gonçalves, 1998), it was found that 11 animals were infected with strongylids and 42 were infected with S. papillosus.

Third-stage larvae (L3) of H. contortus (82\%) and T. colubriformis (18\%) were identified in composite fecal cultures (Ueno \& Gonçalves, 1998). In order to eliminate nematode infections, all the animals were treated with a combination of monepantel (2.5 mg/kg; Zolvix ${ }^{\circledR}$, Novartis), albendazole $\left(10 \mathrm{mg} / \mathrm{kg}\right.$; Valbazen ${ }^{\circledR}$, Pfizer) and levamisole $(10 \mathrm{mg} / \mathrm{kg}$; Ripercol ${ }^{\circledR}$, Dodge Fort). No nematode eggs were found in fecal examinations performed 14 days after this treatment. The concrete floor of the premises was washed with water under pressure every second day, to prevent reinfection.

All the lambs received a clostridial vaccine (Sintoxan Polivalente ${ }^{\circledR}$, Merial) and toltrazuril $(20 \mathrm{mg} / \mathrm{kg}$; Baycox®, Pfizer) to prevent coccidiosis.

The experiment used a completely randomized $2 \times 4$ factorial design (infected or control $\times$ four diets). The concentrate used in the diets of this experiment consisted of ground corn, soybean meal, calcitic limestone, 
urea and ammonium chloride, the amounts described in the Table 1. The 44 animals were randomized to the eight treatments as follows:

- Diet 1 - Infected $(n=7)$ : only hay;

- Diet 1 - Control $(n=4)$ : only hay;

- Diet 2 - Infected ( $n=7)$ : proportions of $75 \%$ hay and $25 \%$ concentrate;

- Diet 2 - Control $(n=4)$ : proportions of $75 \%$ hay and $25 \%$ concentrate;

- Diet 3 - Infected ( $n=7$ ): proportions of 50\% hay and 50\% concentrate;

- Diet 3 - Control $(n=4)$ : proportions of $50 \%$ hay and $50 \%$ concentrate;

- Diet 4 - Infected $(n=7)$ : proportions of $25 \%$ hay and $75 \%$ concentrate. One animal in this group was excluded from the experiment because it did not adapt to the diet and showed clinical signs of ruminal acidosis. For this reason, this group was made up of six lambs.

- Diet 4 - Control $(n=4)$ : proportions of $25 \%$ hay and $75 \%$ concentrate.

Table 1 describes the ingredients of the diets and the nutritional composition, based on rumen simulation. The diets were formulated in accordance with the national research council (NRC, 2007), in order to meet the requirements of growing lambs (maturity of 0.3 ) and estimated daily gains of 67, 130, 213 or $302 \mathrm{~g} /$ day for diets 1 , 2, 3 and 4, respectively. The computer program Small Ruminant Nutrition System (SRNS), based on the structure of the Cornell Net Carbohydrate and Protein System (CNCPS, 2000), was used to formulate the diets. We used ground coast cross hay (Cynodon dactylon) acquired from a farm where there were no ruminants, in order to prevent undesirable L3 contamination.

Before the beginning of the serial infections, the animals were subjected to a period of adaptation to the diets over three weeks. At the time of the initial infection, the lambs were four months of age and had a mean body weight of $31.5 \pm 3.24 \mathrm{~kg}$.

Table 1. Ingredients and nutritional composition of the four experimental diets.

\begin{tabular}{|c|c|c|c|c|}
\hline & Diet 1 & Diet 2 & Diet 3 & Diet 4 \\
\hline \multicolumn{5}{|l|}{ Ingredients, $\%$ of dry matter (DM) } \\
\hline Ground hay (Cynodon dactylon) & 97.76 & 73.49 & 49.10 & 24.60 \\
\hline Ground corn (maize) & 0.00 & 20.84 & 41.78 & 62.78 \\
\hline Soybean meal & 0.00 & 3.09 & 6.19 & 9.30 \\
\hline Calcitic limestone & 0.00 & 0.38 & 0.76 & 1.15 \\
\hline Urea & 0.00 & 0.19 & 0.37 & 0.56 \\
\hline Mineral ${ }^{1}$ & 1.57 & 1.41 & 1.25 & 1.13 \\
\hline Ammonium chloride & 0.67 & 0.61 & 0.53 & 0.48 \\
\hline \multicolumn{5}{|l|}{ Chemical composition, DM basis² } \\
\hline Dry matter, \% & 88.32 & 88.39 & 88.34 & 88.31 \\
\hline Crude protein, $\%$ & 8.50 & 10.4 & 12.30 & 14.20 \\
\hline Rumen degradable protein, \% PB & 58.10 & 59.90 & 61.1 & 63.20 \\
\hline Metabolizable protein, \% & 7.41 & 8.79 & 10.18 & 11.53 \\
\hline Metabolizable energy, kcal/kg & 1861 & 2133 & 2418 & 2726 \\
\hline Effective NDF, \% & 74.04 & 57.07 & 40.36 & 23.46 \\
\hline Ether extract, \% & 1.50 & 2.10 & 2.70 & 3.40 \\
\hline Calcium, \% & 0.67 & 0.70 & 0.71 & 0.73 \\
\hline Phosphor, \% & 0.30 & 0.31 & 0.35 & 0.40 \\
\hline
\end{tabular}

${ }^{1}$ Mineral composition (kg of the product) $200 \mathrm{~g} \mathrm{Ca}, 75 \mathrm{~g} \mathrm{P}, 50 \mathrm{~g} \mathrm{Mg}, 10 \mathrm{mg} \mathrm{S}, 24 \mathrm{mg}$ Se, $3060 \mathrm{mg}$ Zn, $1000 \mathrm{mg}$ Mn, $2500 \mathrm{mg}$ I and 20 mg Co.; ${ }^{2}$ Values calculated by means of CNCPS - sheep software. 
The lambs were kept in individual pens $\left(3 \mathrm{~m}^{2}\right)$, where they had free access (ad libitum) to the diets and water. Food was provided twice a day, at 8 am and $4 \mathrm{pm}$. The voluntary consumption of each animal was measured daily through the difference between the weight of the diet offered and the weight of the leftovers collected the next morning. The amount of food offered was adjusted daily during the experiment, such that the proportions of leftovers would be up to $20 \%$ of the total offered for Diet 1 and $10 \%$ for the other diets.

\section{Production of infective larvae and serial infections}

The infective larvae used in this experiment were from $T$. colubriformis and $H$. contortus isolates, which had been kept frozen in liquid nitrogen. Complete information about these isolates was provided by Almeida et al. (2010). For production of L3, we used two donor lambs for each nematode species. Fecal samples from these monoinfected donor animals were collected for production of infective larvae in fecal cultures (Ueno \& Gonçalves, 1998).

Each animal in the infected group received 1,000 L3 of $H$. contortus and 1,000 L3 of $T$. colubriformis every three days, thus totaling 28,000 infective larvae of each species over the 12 weeks of the infection period.

\section{Measurements}

The animals were weighed weekly. On the same day, fecal and blood samples were taken from each lamb. The fecal samples were individually processed using the modified McMaster technique, with a sensitivity of 100 EPG (Ueno \& Gonçalves, 1998). Composite fecal cultures were prepared for each group to obtain and differentiate third-stage larvae into parasite genera (Ueno \& Gonçalves, 1998). Blood samples $(5 \mathrm{~mL})$ were collected by means of jugular vein puncture into Vacutainer ${ }^{\circledR}$ tubes containing anticoagulant (EDTA). The packed cell volume (PCV) was determined by means of microhematocrit centrifugation, and the total plasma protein (TPP) levels were estimated using a refractometer (Refractometer SPR-N, Atago).

\section{Statistical analysis}

The data were assessed using analysis of variance for the variables with just one measurement (initial and final body weight, daily body weight gain, carcass weight and daily food consumption) using the General Linear Models (GLM) procedure of the Statistical Analysis System, version 9.4 (SAS Institute, 2016). For the weekly measurements (PCV and TPP), repeated-measurement analysis of the GLM procedure was used. Diet and infection status were the classes evaluated. Averages were compared by means of Tukey's test at a 5\% significance level, and only significant interactions at this level were reported in the results. Data on EPG were analyzed under log transformation (Log (EPG+100)).

\section{Results}

The non-infected control lambs did not shed eggs in feces during the trial. There was no significant time $x$ diet interaction regarding FEC in the infected groups. Overall, the Diet 4 group showed the lowest mean FEC and the Diet 1 group, the highest (Figure 1). Statistically significant group mean differences $(P<0.05)$ were observed, as follows: Diet 4 lower than Diets 2 and 3 at days 21 and 28; and Diet 4 lower than Diet 1 at days 28, 35 and 49. On average, the proportions of $\mathrm{H}$. contortus and $\mathrm{T}$. colubriformis infective larvae produced in fecal cultures were, respectively, the following: $76 \%$ and $24 \%$ in Diet $1 ; 63 \%$ and $37 \%$ in Diet 2; $49 \%$ and $51 \%$ in Diet 3; and 36\% and 64\% in Diet 4.

With regard to PCV and TPP, there were significant time $x$ diet $x$ infection interactions $(P<0.01)$. In comparison with the non-infected controls, there were decreases in the means of these variables in all infected groups. However, this decrease was most pronounced in the Diet 1 infected group, which presented mean PCV below $24 \%$ and TPP below $6 \mathrm{~g} / \mathrm{dL}$ from day 49 until the end of the trial (Figure 2). In this group, two lambs presented severe anemia at the last sampling (both with PCV $=11 \%$; and TPP $=4.8 \mathrm{~g} / \mathrm{dL}$ and $4.0 \mathrm{~g} / \mathrm{dL}$ ). In Diet 1 , significant differences $(P<0.05)$ between the PCV of infected lambs and their counterpart controls were seen at days 49, 63, 70, 77 and 84; and in Diet 2 at day 84. Concerning TPP (Figure 3), in Diet 1 significant differences $(P<0.05)$ between infected lambs and their counterpart controls were seen at days 49, 56, 63, 70, 77 and 84 . In the other diets, lower mean TPP was seen in the infected lambs than in the non-infected control counterparts, but without a significant difference between these groups. 


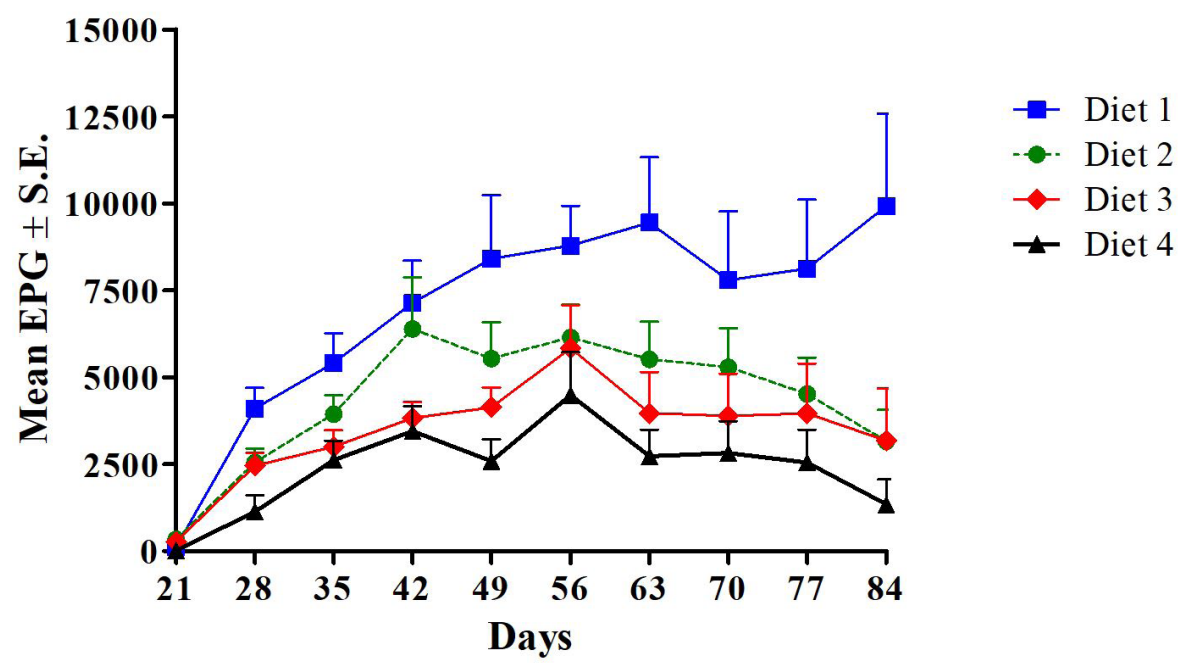

Figure 1. Mean number of eggs per gram of feces (EPG) of the lambs that were artificially infected every three days with 1000 larvae (L3) of $H$. contortus and 1000 L3 of $T$. colubriformis. The lambs were fed with one of the following four diets: Diet 1 (7.4\% of metabolizable protein (MP) and $1861 \mathrm{kcal} / \mathrm{kg}$ of metabolizable energy (ME)); Diet 2 (8.8\% MP and $2133 \mathrm{kcal} / \mathrm{kg} \mathrm{ME})$; Diet 3 (10.2\% MP and $2418 \mathrm{kcal} / \mathrm{kg} \mathrm{ME);} \mathrm{and} \mathrm{Diet} 4$ (11.5\% MP and $2726 \mathrm{kcal} / \mathrm{kg} \mathrm{ME}$ ). Bars = standard error (S.E.).

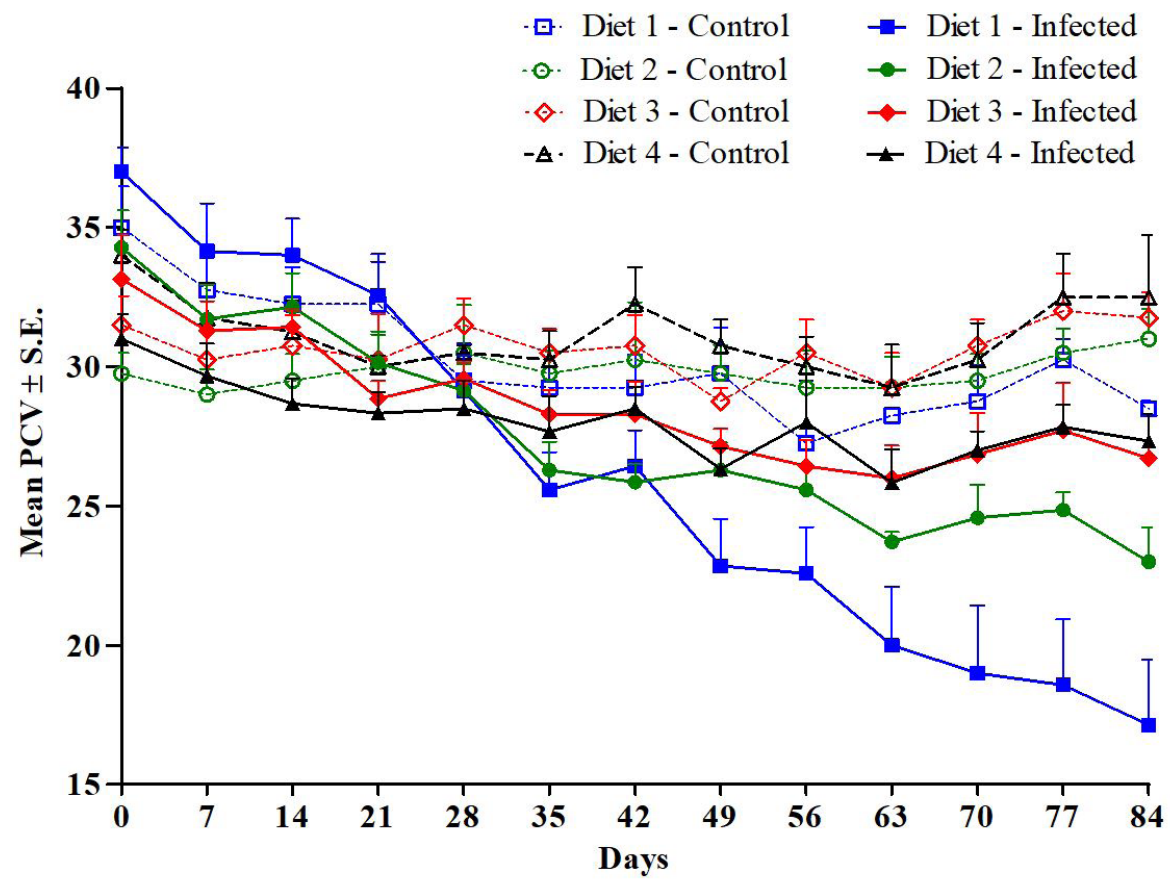

Figure 2. Mean packed cell values (PCV, \%) of the non-infected control lambs and of the lambs that were artificially infected every three days with 1000 larvae (L3) of H. contortus and $1000 \mathrm{~L} 3$ of T. colubriformis. The lambs were fed with one of the following four diets: Diet 1 (7.4\% of metabolizable protein (MP) and $1861 \mathrm{kcal} / \mathrm{kg}$ of metabolizable energy (ME)); Diet 2 (8.8\% MP and $2133 \mathrm{kcal} / \mathrm{kg} \mathrm{ME})$; Diet 3 (10.2\% MP and $2418 \mathrm{kcal} / \mathrm{kg} \mathrm{ME);} \mathrm{and} \mathrm{Diet} 4$ (11.5\% MP and $2726 \mathrm{kcal} / \mathrm{kg} \mathrm{ME}$ ). Bars = standard error (S.E.).

All the groups of lambs presented similar body weight at the beginning of the trial (Table 2). There were statistically significant diet and infection effects on daily body weight gain, cold carcass weight and daily food consumption (Table 2). The increase in the metabolizable protein and energy content in the diets corresponded to higher overall group averages for those variables. Conversely, the infected groups showed reduced daily body weight gain, cold carcass weight and food consumption in comparison with the non-infected controls. The Diet 1 infected group presented the lowest daily food consumption $(0.862 \mathrm{~kg} /$ day $)$ and the lowest daily body weight gain $(0.025 \mathrm{~kg} / \mathrm{day})$, while the Diet 4 control group had the highest values: daily food consumption $=1.638 \mathrm{~kg} / \mathrm{day}$ and daily body weight gain $=0.303 \mathrm{~kg} /$ day . 


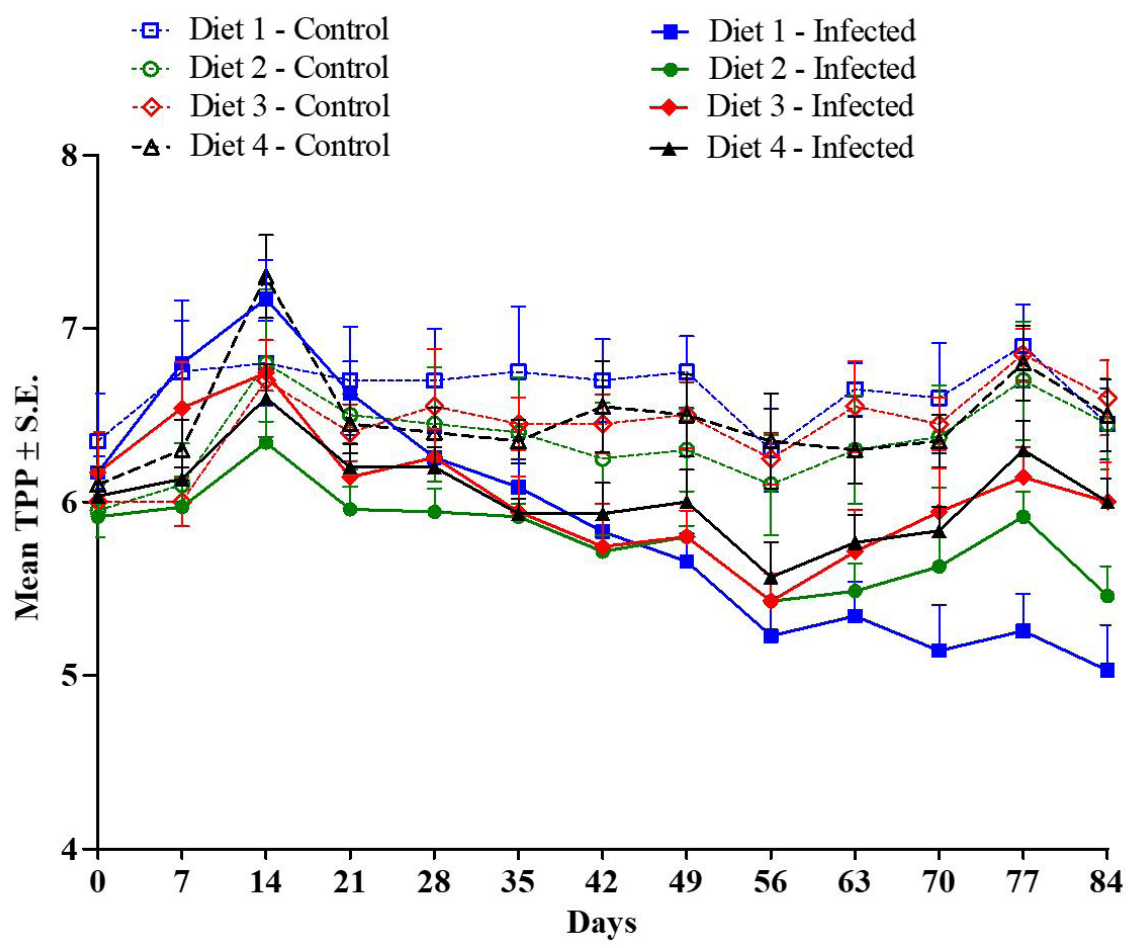

Figure 3. Mean total plasma protein (TPP, $\mathrm{g} / \mathrm{dL}$ ) of the non-infected control lambs and of the lambs artificially infected every three days with 1000 larvae (L3) of H. contortus and 1000 L3 of T. colubriformis. The lambs were fed with one of the following four diets: Diet 1 (7.4\% of metabolizable protein (MP) and $1861 \mathrm{kcal} / \mathrm{kg}$ of metabolizable energy (ME)); Diet 2 (8.8\% MP and $2133 \mathrm{kcal} / \mathrm{kg} \mathrm{ME})$; Diet 3 (10.2\% MP and $2418 \mathrm{kcal} / \mathrm{kg} \mathrm{ME);} \mathrm{and} \mathrm{Diet} 4$ (11.5\% MP and $2726 \mathrm{kcal} / \mathrm{kg} \mathrm{ME}$ ). Bars = standard error (S.E.).

Table 2. Average ( \pm standard error) of variables (in $\mathrm{kg}$ ) relating to performance of the non-infected control lambs and of the lambs that were artificially infected every three days with 1000 larvae (L3) of $H$. contortus and $1000 \mathrm{~L} 3$ of $T$. colubriformis. The lambs were fed with one of the following four diets: Diet 1 (7.4\% of metabolizable protein (MP) and $1861 \mathrm{kcal} / \mathrm{kg}$ of metabolizable energy (ME)); Diet 2 (8.8\% MP and $2133 \mathrm{kcal} / \mathrm{kg} \mathrm{ME})$; Diet 3 (10.2\% MP and $2418 \mathrm{kcal} / \mathrm{kg} \mathrm{ME})$; or Diet 4 (11.5\% MP and $2726 \mathrm{kcal} / \mathrm{kg} \mathrm{ME})$.

\begin{tabular}{|c|c|c|c|c|c|c|c|c|}
\hline \multirow{2}{*}{ Variable } & \multirow{2}{*}{$\begin{array}{l}\text { Parasitological } \\
\text { status }\end{array}$} & \multirow{2}{*}{ Diet 1} & \multirow{2}{*}{ Diet 2} & \multirow{2}{*}{ Diet 3} & \multirow{2}{*}{ Diet 4} & \multirow{2}{*}{ Overall mean } & \multicolumn{2}{|c|}{ P-value } \\
\hline & & & & & & & Diet & Infection \\
\hline \multirow{3}{*}{$\begin{array}{l}\text { Initial body } \\
\text { weight } \\
\text { (Day 0) }\end{array}$} & Control & $32.7 \pm 2.46$ & $31.4 \pm 1.18$ & $32.7 \pm 2.11$ & $31.1 \pm 0.36$ & $32.0 \pm 0.80$ & 0.910 & 0.743 \\
\hline & Infected & $30.5 \pm 1.26$ & $32.8 \pm 1.42$ & $31.4 \pm 1.60$ & $31.8 \pm 1.21$ & $31.6 \pm 0.68$ & & \\
\hline & Overall mean & $31.3 \pm 1.18$ & $32.3 \pm 0.98$ & $31.8 \pm 1.22$ & $31.5 \pm 0.72$ & & & \\
\hline \multirow{3}{*}{$\begin{array}{c}\text { Final body } \\
\text { weight } \\
\text { (Day 84) }\end{array}$} & Control & $36.8 \pm 2.63$ & $38.3 \pm 1.39$ & $48.5 \pm 2.19$ & $56.5 \pm 0.96$ & $45.0 \pm 2.24 \mathrm{~A}$ & $<0.001$ & 0.069 \\
\hline & Infected & $32.5 \pm 1.29$ & $38.5 \pm 1.25$ & $47.3 \pm 1.66$ & $50.3 \pm 3.48$ & $41.9 \pm 1.66$ B & & \\
\hline & Overall mean & $34.1 \pm 1.34 \mathrm{a}$ & $38.4 \pm 0.90 a$ & $47.7 \pm 1.27 b$ & $52.8 \pm 2.28 b$ & & & \\
\hline \multirow{3}{*}{$\begin{array}{l}\text { Daily body } \\
\text { weight gain }\end{array}$} & Control & $0.048 \pm 0.0049$ & $0.082 \pm 0.0056$ & $0.188 \pm 0.0032$ & $0.303 \pm 0.0128$ & $0.155 \pm 0.0260 \mathrm{~A}$ & $<0.001$ & 0.011 \\
\hline & Infected & $0.025 \pm 0.0056$ & $0.067 \pm 0.0066$ & $0.189 \pm 0.0090$ & $0.221 \pm 0.0328$ & $0.122 \pm 0.0176 \mathrm{~B}$ & & \\
\hline & Overall mean & $0.033 \pm 0.0052 \mathrm{a}$ & $0.073 \pm 0.0050 a$ & $0.189 \pm 0.0056 b$ & $0.254 \pm 0.0237 c$ & & & \\
\hline \multirow{3}{*}{$\begin{array}{c}\text { Cold carcass } \\
\text { weight }\end{array}$} & Control & $14.1 \pm 1.31$ & $16.3 \pm 0.74$ & $22.3 \pm 1.09$ & $27.0 \pm 0.26$ & $19.9 \pm 1.38 \mathrm{~A}$ & $<0.001$ & 0.005 \\
\hline & Infected & $11.5 \pm 0.53$ & $16.4 \pm 0.70$ & $20.4 \pm 0.72$ & $23.0 \pm 1.54$ & $17.6 \pm 0.94 \mathrm{~B}$ & & \\
\hline & Overall mean & $12.4 \pm 0.67 a$ & $16.4 \pm 0.50 \mathrm{~b}$ & $21.1 \pm 0.64 \mathrm{c}$ & $24.6 \pm 1.11 \mathrm{~d}$ & & & \\
\hline \multirow{3}{*}{$\begin{array}{l}\text { Daily food } \\
\text { consumption }\end{array}$} & Control & $1.016 \pm 0.124$ & $1.262 \pm 0.119$ & $1.529 \pm 0.079$ & $1.638 \pm 0.090$ & $1.361 \pm 0.078 \mathrm{~A}$ & $<0.001$ & 0.035 \\
\hline & Infected & $0.862 \pm 0.089$ & $1.176 \pm 0.111$ & $1.376 \pm 0.089$ & $1.301 \pm 0.149$ & $1.174 \pm 0.064 \mathrm{~B}$ & & \\
\hline & Overall mean & $0.918 \pm 0.072 a$ & $1.207 \pm 0.080 a b$ & $1.432 \pm 0.065 b$ & $1.436 \pm 0.107 b$ & & & \\
\hline
\end{tabular}

For each variable, different lowercase letters on the same line and different uppercase letters in the same column indicate significant statistical differences. (Tukey's test; $\mathrm{P}<0.05$ ). In the analysis on all the variables, there was no significant interaction for diet $\mathrm{x}$ infection $(\mathrm{P}>0.05)$. 


\section{Discussion}

We evaluated simultaneous infections with the most important species of nematodes that infect sheep, $H$. contortus and T. colubriformis. We attempted to simulate ingestion of L3 by grazing animals, which is typical of Brazilian sheep farming conditions. The losses recorded in the infected animals of the present study were consequences of the alterations produced by both nematodes.

The infected lambs of the present study showed changes to hematological variables, with decreases in PCV and TPP concentration, in comparison with their control counterparts. Both nematode species have been implicated in such changes. In lambs, the main deleterious effect of parasitism by $\mathrm{H}$. contortus is anemia (Carvalho et al., 2015), whereas in the case of parasitism by T. colubriformis the main deleterious effects are due to immunopathological changes to the small intestine mucosa (Cardia et al., 2011; Dias-Silva et al., 2020). The losses of endogenous proteins result in a net loss of amino acids, along with an imbalance in energy and mineral metabolism (van Houtert \& Sykes, 1996).

In the present experiment, the influence of the diet on the animals' performance was evident: the weight gain was proportional to the amount of protein and metabolizable energy in the diets. Several animals in the group that only received hay presented hypoproteinemia and severe anemia, while the decreases in PCV and TPP were more subtle in the supplemented animals. Therefore, the greater the amounts of these nutrients were, the greater the values of PCV and TPP also were, such that these animals demonstrated higher ability to withstand the adverse effects of infection. These results are in agreement with reports from studies carried out on lambs experimentally infected with $\mathrm{H}$. contortus, in which increased resilience was seen among the supplemented animals (Wallace et al., 1995; Bricarello et al., 2005; Carvalho et al., 2015). In field studies conducted in Brazil on young lambs, benefits from supplementation have also been demonstrated: the animals became more resistant/resilient to natural infections with GINs, with increased productive performance (Louvandini et al., 2006; Melo et al., 2017; Starling et al., 2019).

The infections of the present study caused decreased food consumption, regardless of the type of diet. This had a consequential negative impact on daily body weight gain and carcass weight. Overall, the infected animals showed a $13.7 \%$ reduction in food consumption, $21.3 \%$ reduction in daily body weight gain and $16.6 \%$ reduction in cold carcass weight, in comparison with the non-infected controls. The depression of appetite is attributed to the discomfort produced by the lesions and the inflammatory reaction caused by the parasites in the mucosa of the gastrointestinal tract. In addition, $T$. colubriformis causes villous atrophy, which also impairs digestion and absorption of nutrients (Greer et al., 2005; Cardia et al., 2011). In Santa Inês lambs that were experimentally infected with $T$. colubriformis over a 13-week period ( $2500 \mathrm{L3}$, three times a week), a small reduction in voluntary food consumption was observed, but there was a large diminution of daily weight gain: the infected group showed a $37 \%$ reduction in daily weight gain (107.3 g/day) in comparison with the control group (171.1 g/day) (Cardia et al., 2011).

Voluntary food consumption is also affected by $\mathrm{H}$. contortus infection. Infected lambs had lower consumption when they had lower protein intake, receiving a diet with 10,13 or $16 \% \mathrm{CP}$, whereas animals with a diet containing 19 or $22 \%$ CP do not show a reduction in consumption in the face of parasitism. Moreover, the effect of parasitism is more evident in infected animals receiving less protein, these associated factors compromise the animals' weight gain (Datta et al., 1998).

Our results agree with the premise that the nutritional cost of acquisition and maintenance of immunity differs according to the age and previous experience of the host. Productivity is very little affected after the effective establishment of the immune response in older animals, while it is compromised through reduction in voluntary food consumption during the immunity acquisition phase in lambs (Greer et al., 2005), which was the case among the young animals in our study.

The present study demonstrated that diets that are rich in nutrients not only increase the resilience of animals but also enable reduction of the time needed for lambs to reach carcass weights of between 18 and $22 \mathrm{~kg}$, which are considered to be the ideal for Dorper lambs (Cloete et al., 2000). Reduction of the length of the fattening period translates into lower costs relating to facilities and labor, and perhaps most importantly nowadays, this can contribute to reduction of greenhouse gas emissions from the livestock sector, through increasing the efficiency of the production system (Houdijk et al., 2017).

In view of the low efficiency of the use of anthelmintics for prophylaxis against GIN infections, which has made it challenging to raise young animals on pasture, our results indicate that the productivity of lamb fattening can be increased in feedlots, through supplying a balanced diet, free from L3 contamination. Obviously, adoption of confinement as a regime for fattening of lambs depends on the economic analysis, given that the main ingredients used in formulation of the concentrate (corn and soybean meal) are commodities that vary in price depending 
on the international market. Alternatively, satisfactory weight gain among young sheep and successful prophylaxis against GIN infections can also be achieved through use of clean pastures, which can be produced in integrated crop-livestock systems, in association with supplementation (Almeida et al., 2018b).

In conclusion, $H$. contortus and $T$. colubriformis mix-infection causes diminution of food consumption and reduction of production performance regardless of the diet, among young Dorper lambs. However, with increased metabolizable protein and energy in the diet, the risk of occurrence of anemia and hypoproteinemia is reduced.

\section{Acknowledgements}

N. Carvalho received financial support from CAPES (Coordenação de Aperfeiçoamento de Pessoal de Nível Superior), J. H. das Neves from FAPESP (Fundação de Amparo à Pesquisa do Estado de São Paulo, Project 2014/02961-0); Caio Santos Pennacchi from PIBIC-CNPq; and A. F. T. Amarante is a recipient of a fellowship from CNPq (Conselho Nacional de Desenvolvimento Científico e Tecnológico; 305187/2017-1). This study was funded by FAPESP (grant 2015/14751-3).

\section{References}

Albuquerque ACA, Bassetto CC, Almeida FA, Amarante AFT. Development of Haemonchus contortus resistance in sheep under suppressive or targeted selective treatment with monepantel. Vet Parasitol 2017; 246: 112-117. http://dx.doi.org/10.1016/j. vetpar.2017.09.010. PMid:28969773.

Almeida FA, Bassetto CC, Amarante MRV, Albuquerque ACA, Starling RZC, Amarante AFT. Helminth infections and hybridization between Haemonchus contortus and Haemonchus placei in sheep from Santana do Livramento, Brazil. Rev Bras Parasitol Vet 2018a; 27(3): 280-288. http://dx.doi.org/10.1590/s1984-296120180044.

Almeida FA, Garcia KCOD, Torgerson PR, Amarante AFT. Multiple resistance to anthelmintics by Haemonchus contortus and Trichostrongylus colubriformis in sheep in Brazil. Parasitol Int 2010; 59(4): 622-625. http://dx.doi.org/10.1016/j.parint.2010.09.006. PMid:20887800.

Almeida FA, Piza MLST, Bassetto CC, Starling RZC, Albuquerque ACA, Protes VM, et al. Infection with gastrointestinal nematodes in lambs in different integrated crop-livestock systems (ICL). Small Rumin Res 2018b; 166: 66-72. http://dx.doi.org/10.1016/j. smallrumres.2018.07.009.

Bricarello PA, Amarante AFT, Rocha RA, Cabral SL Fo, HuntleyJF, HoudijkJGM, et al. Influence of dietary protein supply on resistance to experimental infections with Haemonchus contortus in lle de France and Santa Ines lambs. Vet Parasito/ 2005; $134(1-2)$ : $99-109$. http://dx.doi.org/10.1016/j.vetpar.2005.05.068. PMid:16098676.

Cardia DFF, Rocha-Oliveira RA, Tsunemi MH, Amarante AFT. Immune response and performance of growing Santa Ines lambs to artificial Trichostrongylus colubriformis infections. Vet Parasitol 2011; 182(2-4): 248-258. http://dx.doi.org/10.1016/j. vetpar.2011.05.017. PMid:21641720.

Carvalho N, das Neves JH, Nazato C, Louvandini H, Amarante AF. The effects of diet and corticosteroid-induced immune suppression during infection by Haemonchus contortus in lambs. Vet Parasito/ 2015; 214(3-4): 289-294. http://dx.doi.org/10.1016/j. vetpar.2015.09.012. PMid:26391820.

Cloete SWP, Snyman MA, Herselman MJ. Productive performance of Dorper sheep. Small Rumin Res 2000; 36(2): 119-135. http:// dx.doi.org/10.1016/S0921-4488(99)00156-X. PMid:10760448.

Cornell Net Carbohydrate and Protein System - CNCPS. The net carbohydrate and protein system for evaluating herd nutrition and nutrients excretion. Version 5.0. Ithaca: CNCPS; 2000. 237 p.

Datta FU, Nolan JV, Rowe JB, Gray GD. Protein supplementation improves the performance of parasitised sheep fed a straw-based diet. Int J Parasitol 1998; 28(8): 1269-1278. http://dx.doi.org/10.1016/S0020-7519(98)00104-0. PMid:9762574.

Dias-Silva TP, Abdalla AL Fo, Katiki LM, Amarante AFT, Abdalla AL, Louvandini H. Trichostrongylus colubriformis infection in Santa Inês lambs: impact on feed digestibility, blood markers, and nitrogen balance. Rev Bras Parasito/ Vet 2020; 29(2): e002220. http:// dx.doi.org/10.1590/s1984-29612020026. PMid:32428186.

Flávia da Silva F, Bezerra HMFF, Feitosa TF, Vilela VLR. Nematode resistance to five anthelmintic classes in naturally infected sheep herds in Northeastern Brazil. Rev Bras Parasitol Vet 2018; 27(4): 423-429. http://dx.doi.org/10.1590/s1984-296120180071. PMid:30427525.

Greer AW, Stankiewicz M, Jay NP, McAnulty RW, Sykes AR. The effect of concurrent corticosteroid induced immuno-suppression and infection with the intestinal parasite Trichostrongylus colubriformis on food intake and utilization in both immunologically naïve and competent sheep. Anim Sci 2005; 80(1): 89-99. http://dx.doi.org/10.1079/ASC41100089. 
Greer AW. Trade-offs and benefits: implications of promoting a strong immunity to gastrointestinal parasites in sheep. Parasite Immunol 2008; 30(2): 123-132. http://dx.doi.org/10.1111/j.1365-3024.2008.00998.x. PMid:18186772.

Hoste H, Torres-Acosta JFJ, Quijada J, Chan-Perez I, Dakheel MM, Kommuru DS, et al. Chapter seven - Interactions between nutrition and infections with Haemonchus contortus and related gastrointestinal nematodes in small ruminants. Adv Parasitol 2016; 93: 239-351. http://dx.doi.org/10.1016/bs.apar.2016.02.025. PMid:27238007.

Houdijk JGM, Tolkamp BJ, Rooke JA, Hutchings MR. Animal health and greenhouse gas intensity: the paradox of periparturient parasitism. Int J Parasitol 2017; 47(10-11): 633-641. http://dx.doi.org/10.1016/j.ijpara.2017.03.006. PMid:28528874.

Louvandini H, Veloso CFM, Paludo GR, Dell'Porto A, Gennari SM, McManus CM. Influence of protein supplementation on the resistance and resilience on young hair sheep naturally infected with gastrointestinal nematodes during rainy and dry seasons. Vet Parasitol 2006; 137(1-2): 103-111. http://dx.doi.org/10.1016/j.vetpar.2006.01.004. PMid:16495016.

Mavrot F, Hertzberg H, Torgerson P. Effect of gastro-intestinal nematode infection on sheep performance: a systematic review and meta-analysis. Parasit Vectors 2015; 8(1): 557. http://dx.doi.org/10.1186/s13071-015-1164-z. PMid:26496893.

Melo GKA, Ítavo CCBF, Monteiro KLS, Silva JA, Silva PCG, Ítavo LCV, et al. Effect of creep-fed supplement on the susceptibility of pasture-grazed suckling lambs to gastrointestinal helminths. Vet Parasitol 2017; 239: 26-30. http://dx.doi.org/10.1016/j. vetpar.2017.04.017. PMid:28495192.

Méndez-Ortíz FA, Sandoval-Castro CA, Vargas-Magaña JJ, Sarmiento-Franco L, Torres-Acosta JFJ, Ventura-Cordero J. Impact of gastrointestinal parasitism on dry matter intake and live weight gain of lambs: A meta-analysis to estimate the metabolic cost of gastrointestinal nematodes. Vet Parasito/ 2019; 265: 1-6. http://dx.doi.org/10.1016/j.vetpar.2018.11.008. PMid:30638514

Mugambi JM, Bain RK, Wanyangu SW, Ihiga MA, Duncan JL, Murray M, et al. Resistance of four sheep breeds to natural and subsequent artificial Haemonchus contortus infection. Vet Parasitol 1997; 69(3-4): 265-273. http://dx.doi.org/10.1016/S03044017(96)01128-4. PMid:9195736.

National Research Council of the National Academies - NRC. Nutrient requirements of small ruminants: sheep, goats, cervids, and new world camelids. Washington, D.C: National Academy Press; 2007.

Salgado JA, Cruz LV, Rocha LO, Sotomaior CS, Borges TD, Santos CP. Implication of the fecal egg count reduction test (FECRT) in sheep for better use of available drugs. Rev Bras Parasito/ Vet 2019; 28(4): 700-707. http://dx.doi.org/10.1590/s1984-29612019093. PMid:31800888.

SAS Institute. SAS user's guide. Version 9.4 [online]. Cary, NC: SAS Institute Inc.; 2016 [cited 2020 Nov 10]. Available from: https:// support.sas.com/

Starling RZC, Almeida FA, Viana MVG, Castilhos AM, Amarante AFT. Losses caused by gastrointestinal nematode infections in Dorper lambs under two nutritional status. Rev Bras Parasitol Vet 2019; 28(4): 652-660. http://dx.doi.org/10.1590/s198429612019084 . PMid:31691735.

Ueno H, Gonçalves PC. Manual para diagnóstico das helmintoses de ruminantes. 4. ed. Tokyo: Japan International Cooperation Agency; 1998.

van Houtert MF, Sykes AR. Implications of nutrition for the ability of ruminants to withstand gastrointestinal nematode infections. Int J Parasitol 1996; 26(11): 1151-1167. http://dx.doi.org/10.1016/S0020-7519(96)00120-8. PMid:9024860.

Wallace DS, Bairden K, Duncan JL, Fishwick G, Gill M, Holmes PH, et al. Influence of supplementation with dietary soybean meal on resistance to haemonchosis in Hampshire down lambs. Res Vet Sci 1995; 58(3): 232-237. http://dx.doi.org/10.1016/00345288(95)90108-6. PMid:7659847.

Wilmsen MO, Silva BF, Bassetto CC, Amarante AFT. Gastrointestinal nematode infections in sheep raised in Botucatu, State of São Paulo, Brazil. Rev Bras Parasitol Vet 2014; 23(3): 348-354. http://dx.doi.org/10.1590/S1984-29612014058. PMid:25271455. 